\title{
Immunocompetence and Parasitism in Nestlings from Wild Populations
}

\author{
Santiago Merino* \\ Departamento de Ecología Evolutiva, Museo Nacional de Ciencias Naturales-CSIC, J. Gutiérrez Abascal 2, E-28006 \\ Madrid, Spain
}

\begin{abstract}
Summary: Nestling is a defenceless stage in the life of birds in several ways. For instance, the possibilities to escape infection and infestation by several parasitic diseases are greatly reduced in nestlings. This fact implies that a number of strategies and counter strategies could evolve in hosts to avoid parasites and in parasites to locate and exploit young hosts. An increasing number of nestlings in a nest may support more parasites and thus increase competition between siblings to avoid parasitism. In addition, parental effort may vary in the presence of parasites resulting in different effects of parasitism on nestlings. Moreover, nestling investment in immunity may increase in the presence of parasites at least up to a limit marked by the ability of parents to get resources for their nestlings. In this respect, the transfer of immunoglobulins and other resources from the female parent to eggs may be of considerable importance during the first days of nestlings' life. However, increased parental activity may also attract more parasites to the nest. A recent work using a metaanalytical approach suggests that parasite-induced nestling mortality in birds is mainly determined by geographical location and to a smaller extent nest site and parasite prevalence. The naïve immune system of nestlings and the difficulties to avoid infection once the nest has been located, imply a high potential impact of parasites on nestlings. Thus parasites could cause an important reduction of host population productivity through their effects on nestlings.
\end{abstract}

Keywords: Anti-parasitic behaviour, host-parasite interactions, maternal effects, virulence.

\section{INTRODUCTION}

Parasites, by definition, are organisms that negatively affect their hosts. The adverse effects induced by parasites themselves or the costs associated with the host response against parasitism, may result in important physiological and phenotypic costs potentially affecting nestling survival as it has been reported in both experimental and correlative studies [1-4]. In a host-parasite interaction we can distinguish at least two steps [5]. First, parasites must become in contact with hosts and second, they must be able to exploit them. With respect to the first step, the fact that nestlings are constrained to the nest during a relatively long period of time, implies that they have difficulties to avoid parasites once these reach the nest. Nestlings' capacity to avoid parasitic infections at this stage relies on the parents' ability to build the nest out of the reach of parasites and or to reduce their numbers. Once parasites reach the nestlings, the only possibility is to fight off infections. At this stage, parents may transfer some defences to nestlings that are effective during early development [6], but then an adequate immune response from nestlings should be mounted to reduce the effects of infections as they grow older. However, even at more advanced stages of development, nestlings are still dependent on their parents to obtain enough food and/or specific nutrients to mount an effective immune response $[7,8]$ and, therefore, parents may change their allocation of re-

*Address correspondence to this author at the Departamento de Ecología Evolutiva, Museo Nacional de Ciencias Naturales-CSIC, J. Gutiérrez Abascal 2, E-28006 Madrid, Spain; Tel: +34 914111328; Fax: +34 915645078, E-mail: santiagom@mncn.csic.es sources to the entire brood or to specific nestling/s in order to maximise their fitness $[9,10]$. To be able to mount an effective immune reaction is important for nestlings as this would not only avoid development of an infection but also reduce the blood drawn by ectoparasites for instance. These produce local inflammation at the point of biting, usually due to the injection of saliva by the parasite which triggers the immune reaction [11]. This reaction reduces the time for blood sucking, directly or indirectly via the alerting effect of the pruritis caused on the host. In addition, the inflammatory response may also generate a hostile environment for salivatransmitted pathogens [12].

On the other hand, virulence of parasites varies considerably with different factors. For instance, it is expected that parasites transmitted vertically from parents to offspring show a low level of pathogenicity due to the tight relationship between transmission success and number of offspring [13]. Conversely, parasites transmitted horizontally and especially those transmitted by vectors and not by contact are expected to be highly virulent [14]. The variation in both distribution and virulence of diseases may depend on the frequency of transmission which finally may also depend on host density.

\section{AVOIDING CONTACT WITH PARASITES}

Several studies have shown that birds may use different strategies to limit contact with parasites and/or reduce the number of parasites at the nest. Among these, the transport of aromatic plants with volatile compounds to nests as antiparasitic defence has been proposed for several bird species [15-20]. For example, the quantity of pine greenery in nests 
of the Bonelli's eagles (Hieraaetus fasciatus) in south-east Spain is correlated with a lower presence of blowfly larvae (Protocalliphora) at nests and also higher breeding success [21].

Gehlbach and Baldridge [22] described an interesting antiparasitic behaviour by eastern screech owls (Otus asio) which carried live blind snakes (Leptotyphlops dulcis) to nests. Blind snakes survive in nests consuming nest ectoparasites and therefore reducing their number. On occasions birds may build their nest in places were the occurrence of ectoparasites is reduced as it appears to be the case for some species of the genera Zarhynchus and Psarocolius as well as Cacicus cela, the latter preferring to nest close to colonies of wasps (Protopolybia and Stelopolybia) and bees (Trigona). The presence of these insects appears to decrease bird nest infestation by parasitic Philornis flies [23]. Several reports have also shown that nest reuse by birds may have important costs due to the presence of ectoparasites [24,25] and birds look for new places to nest when ectoparasite numbers increase considerably $[26,27]$. For example it is known that the colonial swallow Hirundo pyrrhonota avoid colonies with high number of ectoparasites like bugs and ticks [28-32]. This is also the case for the semicolonial barn swallow when nests are infested by mites [33]. A different situation is achieved when the nestling is growing in a nest were both parents and siblings are from a different species. This is the case of the Great spotted cuckoo (Clamator glandarius) which is reared by magpies (Pica pica). The specific parasites of magpies do not infect Great spotted cuckoo nestlings and therefore the parasitic birds have an additional advantage in the nests of their hosts [34]. Thus brood parasitism is also a good strategy to avoid the effect of some ectoor endoparasites at the nest.

\section{CONFRONTING PARASITES}

Once the parasites have infected nestlings, individual defence is the only response available. In order to mount an effective immune response against parasites nestlings must receive an adequate nutrient supply. An adequate nutrition has been shown experimentally to influence immune response in birds [7] and immune response shows high environmental variability and low additive genetic variance in house martins (Delichon urbica; [35]; see also [36] but see $[37,38])$. In any case, parental effort in response to parasitism is crucial for nestling survival. In a study looking for the effect of parental effort on nestling parasitism Merino et al. [9] showed that it was the low parental effort of pied flycatchers (Ficedula hypoleuca) the cause of nestling infection by trypanosomes and not the contrary. That is, in the event of parasitism parents do not reduce their effort, but broods receiving less parental effort are more likely to be parasitized. However, reduction of parental effort on infected broods is a theoretical possibility as parents may abandon highly parasitized nests and save energy for future reproduction [39]. Ultimately, it is the balance between the probabilities of future reproduction and the potential success of current reproduction that will make the decision to invest in a parasitized brood more or less profitable in terms of fitness. However, it appears that parents try to compensate the effect of parasitism by increasing their effort at least to a certain limit [40-41]. Once this limit is surpassed, nest abandonment and/or nestling death are the usual consequence (see also [41-43]. For example, in the presence of flea infestation male great tits (Parus major) increase food provisioning rate [44]. Based on this results Perrin et al. [45] showed in a theoretical article that increased parental effort could be adaptive and dependent on the trade-offs between current and future reproductive prospects.

Higher activity of parents supplying food to nestlings may also imply higher risks of parasites being attracted to the nest. For example, Tomás et al. [46] and Martínez de la Puente et al. [47] suggest that the higher abundance of biting midges at nests attended by blue tit (Cyanistes caeruleus) females medicated against malarial parasites as compared to control females, may be due to the higher activity of medicated, and therefore healthier, females attending nestlings [48]. In addition, brood size is also one of the main determinants of abundance of biting flies being attracted to nests [47,49], thus implying that a larger number of nestlings at the nest may support more parasites (see also [50]), although the number of parasites per nestling may not vary considerably.

Birds may use other strategies to reduce the effect of infections on their broods. For example, Christe et al. [10] proposed the "tasty chick hypothesis" as a mechanism to save most of the nestlings in a nest from severe parasite effects by sacrificing one of them: the smaller, late hatched nestling, to parasites. However, Saino et al. [51] have shown that late hatched barn swallow nestlings are more immunocompetent and some evidence exists that parasites prefer to feed on larger nestlings and not on the smaller ones [52]. This may be due to the fact that larger nestlings emit more attractants for parasites or are a better food source in spite of them being more immunocompetent $[53,54]$ (but see[55]). However, at least in some cases, parasites may prefer host persistence to host nutritional attractiveness [56]. On the other hand the exposure of female parents to nest ectoparasites allows transmission of maternal antibodies against parasites to nestlings with beneficial effects for the brood at least during the first days post-hatching as shown in great tits (Parus major) infected by fleas $[6,57]$. Transference of maternal carotenoids to egg yolk may also influence immunocompetence in nestlings [58,59]. Nestling sex has also an important influence on the immune system with male nestlings being usually less immunocompetent than females [60-62], which affects nestling growth rate [63] and also the sex bias in laying order in the presence of parasites [64].

Change in parasite pressure within a season due to new emergence of parasites [42] and/or between seasons due to changes in weather conditions [65] may also affect the availability of nutrients and or the allocation of resources to nestlings' immune defence. For example, Merino et al. [66] showed that nestling barn swallows (Hirundo rustica) from second clutches mount stronger immune responses than those from first clutches, with the cost of increased immune response being reflected in a lower increase in mass. Higher levels of immunity in second clutches may be adaptive for nestlings as parasite pressure usually increases as the season progresses $[42,50,67]$. In fact, parasite pressure may shape the optimal investment in immunity [68] although nestling growth rate and immune response also depend on food availability $[8,69]$. 
Therefore, nestling immunocompetence may be a crucial factor to survival to adulthood. This appears to be the case for nestling pied flycatchers which recruitment probability is more tightly related with their response to the phytohemagglutinin assay, a common test of immunocompetence, than to body mass at the nest [70] (see also [71,72]) and also for house martins (Delichon urbica) which immunoglobulin levels are a good predictor of survival [73]. However, nestlings may invest differentially in different components of the immune system probably depending on ecological and genetic influences $[74,75]$ and more studies are necessary to know how this variation affects survival probabilities.

\section{PARASITE VIRULENCE AND IMMUNE DEFENCES}

Parasite virulence could also vary with different factors that finally modulate the strength of parasitism as a selective pressure on birds. For example, Møller et al. [76] reviewed 117 field estimates of parasite-induced nestling mortality in birds, showing that there was significant consistency in mortality among host and parasite taxa. Virulence increased towards the tropics even when controlling by phylogenetic relationships. These authors also found that greater parasite prevalence was associated with reduced virulence. In addition, birds breeding in open nest sites suffered from greater virulence, measured as nestling mortality caused by parasites than hole nesting species. These findings suggest that parasite-induced nestling mortality in birds is mainly determined by geographical location and, to a smaller extent, nest site and prevalence. This is interesting because distribution of diseases is not always uniform. For example, Merino et al. [77] have shown latitudinal gradients in the prevalence of several blood parasites infecting birds in Chile. This fact implies that allocation of resources to immune response should also vary geographically. In this respect, Møller et al. [78] found differences in immune response between populations of altricial bird species breeding in subtropical Spain and temperate Denmark. However, responses were stronger both in adults and nestlings in Denmark than in Spain. This was probably due to a density dependent effect of parasites on host as density of birds was higher in Denmark and therefore birds in this location may allocate more resources to minimize the risk of parasitism. In other words, the level of anti-parasite defence by hosts is determined by levels of productivity and density-dependent parasite-mediated natural selection [78].

Habitat characteristics may also affect the impact of parasitism as shown by Arriero et al. [79]. These authors showed that nestling blue tits growing in mature forest habitats display higher prevalence of fleas and blood parasites, whereas nestlings from degraded forest habitats suffer from higher prevalence of blowflies (Protocalliphora sp.). Nestlings respond to infections by blowflies and Leucocytozoon blood parasites by increasing their levels of stress protein HSP60 in the blood, a protein which is produced in response to several stressors to maintain cellular homeostasis, especially in response to parasitism in birds (see for example [80]). Thus, habitat characteristics indirectly determine growth conditions for forest birds mediated through their association with parasite infections [79] (see also [36]).

On the other hand transmission probabilities are associated with parasite virulence [13], and it is expected that coloniality in birds may be correlated with more virulent parasites as density of hosts increases (see also [81]). In this respect, Møller et al. [82], showed a positive correlation between the immunocompetence of nestlings from several species of swallows and colony size. That is, nestlings from species with larger colony sizes invest more in immunocompetence. Mortality induced by parasites on nestlings is also positively correlated with immunocompetence [83] indicating that higher levels of investment in immune responses are driven by the impact of parasites.

\section{CONCLUSIONS AND FUTURE PROSPECTS}

Parasites are an important selective force for bird populations having significant effects on nestling mortality and probability of future survival. Geographic and density effects of parasitism modulate responses and strategies of host to reduce the impact of diseases on nestlings. The range of antiparasitic responses available to birds vary from behavioural to physiological and those responses may achieve avoidance and/or reduction of the impact of parasites on nestlings, with important fitness effects on the latter. A better understanding of the patterns of distribution of diseases and the determinants of investment in defences against different kinds of parasites, will help clarify how bird strategies have evolved to minimize the impact of their parasites.

One of the main problems faced in the study of the effects of parasites on wild bird populations is to obtain an accurate measure of infection. Prevalences and intensities of infection are usually a rough estimation of the reality, especially in ecological studies where individuals must be maintained alive to record the result of the host-parasite interaction and therefore the extraction and count of each parasite is not possible. In the case of nestlings, the difficulties are even bigger as many infections may still be at their early stages of development in nestlings, although the naïve immune system of nestlings may also allow a fast increase of the pathogen population relatively soon after initial infection. In any case, the use of new molecular tools could improve the accuracy of our estimations of the incidence of several diseases and they are now being increasingly used in the study of several host-parasite systems [84-87]. The other problem faced by studies of parasites in wild populations of birds is the common occurrence of multiple infections. Most individuals in a population are infected by a plethora of parasites and in order to know the real impact of parasitism on hosts we should also know about the outcome of the various interactions among co-infecting parasites. This problem has been partially solved by the use of general immune function estimations, on the basis that if higher immune responses are produced by a host, they will reflect the capacity of the individual to fight off infections. However, the complexity of the immune system of vertebrates and the fact that different kinds of immune responses may affect different pathogens, makes it necessary to obtain measurements of the different branches of the immune systems [74], a task that was relatively difficult in studies in the wild until recently. Nowadays more and more batteries of simple tests are available to estimate immunocompetence and associated responses in wild populations of birds [7, 80, 88-92] but their joint use is still difficult. In addition, some of them provide estimations of the capacity of an individual to respond to an antigen but they do not measure the actual response against infections. In 
this conditions the need of experimental designs altering immunity and/or parasitism are necessary to obtain a good approximation of the host-parasite interaction in nestling birds.

The impact of parasites on nestlings is of considerable importance because they cannot avoid parasitism once the nest is located by parasites and their naive immune system makes them more susceptible to developing infections. Mortality of nestlings caused by parasites may have important consequences for the conservation of populations. For instance, the introduction of new diseases by human disturbance of the natural colonization rate of new habitats by parasites due to climate change may reduce the growth of bird populations [93-95]. Although our knowledge of the effects of parasites on nestlings has improved considerably during the last two decades, the fact that nestlings are only available for research during a relatively short period of time and that estimating the extent of infection and immunity in the wild is not easy, makes it difficult to obtain reliable information on the initial stages of development of hostparasite relationships. However, the considerable importance of parasitism as a selective pressure on nestlings makes it necessary to gather new energy and impulse for the study of parasitism and immunity in nestlings.

\section{ACKNOWLEDGEMENTS}

While writing this work my research was supported by project CGL2006-14129-C02-01 from the Spanish Ministerio de Educación y Ciencia. Constructive comments by Dr. Josué Martínez de la Puente and an anonymous referee considerably improved a first draft of the manuscript.

\section{REFERENCES}

[1] Atkinson CT, Thomas NJ, Hunter DB, Eds. Parasitic diseases of wild birds. Ames: Wiley-Blackwell 2008.

[2] Loye JE, Zuk M, Eds. Bird-parasite interactions. Ecology, evolution and behaviour. Oxford: Oxford University Press 1991.

[3] Clayton DH, Moore J, Eds. Host-parasite evolution. General principles and avian models. Oxford: Oxford University Press 1997.

[4] Lehmann T. Ectoparasites: direct impact on host fitness. Parasitol Today 1993; 9: 8-13.

[5] Combes C. Parasitism. the ecology and evolution of intimate interactions. The Chicago: University of Chicago Press 2001.

[6] Buechler K, Fitze PS, Gottstein B, Jacot A, Richner H. Parasiteinduced maternal response in a natural bird population. $\mathrm{J}$ Anim Ecol 2002; 71: 247-52

[7] Lochmiller RL, Vestey MR, Boren JC. Relationship between protein nutritional status and immuno-competence in northern bobwhite chicks. Auk 1993; 110: 503-10.

[8] Hoi-Leitner M, Romero-Pujante M, Hoi H, Pavlova A. Food availability and immune capacity in serin (Serinus serinus) nestlings. Behav Ecol Sociobiol 2001; 49: 333-39.

[9] Merino S, Potti J, Moreno J. Maternal effort mediates the prevalence of trypanosomes in the offspring of a passerine bird. Proc Natl Acad Sci USA 1996; 93: 5726-30.

[10] Christe P, Møller AP, de Lope F. Immunocompetence and nestling survival in the house martin: the tasty chick hypothesis. Oikos 1998; 83:175-9.

[11] Lehane M. The biology of blood-sucking in insects. $2^{\text {nd }}$ ed. Cambridge: Cambridge University Press 2005.

[12] Wikel SK. Immune responses to arthropods and their products. Ann Rev Entomol 1982; 27: 21-48.

[13] Frank SA. Models of parasite virulence. Quart Rev Biol 1996; 71: 37-78.

[14] Ewald PW. Evolution of infectious diseases. Oxford: Oxford University Press 1994.
[15] Wimberger PH. The use of green plant material in bird nests to avoid ectoparasites. Auk 1984; 101: 615-8.

[16] Bucher EH. Do birds use biological control against nest parasites? Parasitol Today 1988; 4: 1-3.

[17] Clark L. In: Loye JE, Zuk M, Eds. The nest protection hypothesis: the adaptive use of plant secondary compounds by European starlings, Oxford: Oxford University Press 1991; 205-21.

[18] Lafuma L, Lambrechts MM, Raymond M. Aromatic plants in bird nests as a protection against blood-sucking flying insects? Behav Process 2001; 56: 113-20.

[19] Dawson RD. Does fresh vegetation protect avian nests from ectoparasites? an experiment with tree swallows. Can J Zool 2004; 82:1005-10.

[20] Gwinner H, Berger S. European starlings: nestling condition, parasites and green nest material during the breeding season. J Ornithol 2005; 146: 365-71

[21] Ontiveros D, Caro J, Pleguezuelos JM. Green plant material versus ectoparasites in nests of Bonelli's eagle. J Zool 2008; 274: 99-104.

[22] Gehlbach FR, Baldridge RS. Live blind snakes (Leptotyphlops dulcis) in eastern screech owl (Otus asio) nests: a novel commensalism. Oecologia 1987; 71: 560-3.

[23] Smith NG. The advantage of being parasitized. Nature 1968; 219: 690-4.

[24] Møller AP, Erritzøe J. Parasite virulence and host immune defense: host immune response is related to nest reuse in birds. Evolution 1996; 50: 2066-72

[25] Tomás G, Merino S, Moreno J, Morales J. Consequences of nest reuse on parasite burden and female health and condition in blue tits (Cyanistes caeruleus). Anim Behav 2007; 73: 805-14.

[26] Loye JE, Carroll SP. Ectoparasite behavior and its effects on avian nest site selection. Ann Entomol Soc Am 1998; 91:159-63.

[27] Merino S, Potti J. Pied flycatchers prefer to nest in clean nest boxes in an area with detrimental nest ectoparasites. The Condor 1995; 97: 828-31.

[28] Emlen JT. Responses of breeding cliff swallows to nidicolous parasite infestations. Condor 1985; 88: 110-1.

[29] Brown C, Brown MB. Ectoparasitism as a cost of coloniality in cliff swallows (Hirundo pyrrhonota). Ecology 1986; 67: 1206-18.

[30] Brown C, Brown MB. Coloniality in the cliff swallow: effect of group's size on social behavior. Chicago: University of Chicago Press 1996.

[31] Loye JE, Carroll SP. In: Loye JE, Zuk M, Eds. The effect of nest ectoparasite abundance on cliff swallow colony site selection, nestling development, and departure time, Oxford: Oxford University Press 1991; 222-41.

[32] Chapman BR, George JE In: Loye JE, Zuk M, Eds. The effects of ectoparasites on cliff swallow growth and survival, Oxford: Oxford University Press 1991; 69-92.

[33] Møller AP. Advantages and disadvantages of coloniality in the swallow, Hirundo rustica. Anim Behav 1987; 35: 819-32.

[34] Soler JJ, Møller AP, Soler M, Martínez JG. Interaction between a brood parasite and its host in relation to parasitism and immune defence. Evol Ecol Res 1999; 1: 189-210.

[35] Christe P, Møller AP, Saino N, de Lope F. Genetic and environmental components of phenotypic variation in immune response and body size of a colonial bird, Delichon urbica (the house martin). Heredity 2000; 85: 75-83.

[36] Arriero E. Rearing environment effects on immune defence in blue tit Cyanistes caeruleus nestlings. Oecologia 2009; 159: 697-704.

[37] Brinkhof MWG, Heeb P, Kolliker M, Richner H. Immunocompetence of nestling great tits in relation to rearing environment and parentage. Proc R Soc Lond B. 1999; 266: 2315-22.

[38] Cichon M, Sendecka J, Gustafsson L. Genetic and environmental variation in immune response of collared flycatcher nestlings. J Evol Biol 2006; 19: 1701-06.

[39] Bukaciński D, Bukaciński M. The impact of mass outbreaks of black flies (Simuliidae) on the parental behaviour and breeding output of colonial common gulls (Larus canus). Ann Zool Fenn 2000; 37: 43-9.

[40] Merino S, Moreno J, Potti J, de León, A, Rodríguez R. Nest ectoparasites and maternal effort in pied flycatchers. Biol Conserv della Fauna 1998; 102: 200-5.

[41] Bańbura J, Perret P, Blondel J, Thomas DW, Cartan-Son M, Lambrechts MM. Effects of Protocalliphora parasites on nestling food composition in corsican blue tits Parus caeruleus: consequences for nestling performance. Acta Ornithol 2004; 39: 21-31. 
[42] Merino S, Potti J. Mites and blowflies decrease growth and survival in nestling pied flycatchers. Oikos 1995; 73: 95-103.

[43] Merino S, Moreno J, Sanz JJ, Arriero E. Are avian blood parasites pathogenic in the wild? a medication experiment in blue tits. Proc R Soc Lond B 2000; 267: 2507-10.

[44] Christe P, Richner H, Oppliger A. Begging, food provisioning, and nestling competition in great tit broods infested with ectoparasites. Behav Ecol 1996; 7: 127-31.

[45] Perrin N, Christe P, Richner H. On host life history response to parasitism. Oikos 1996; 75: 317-20.

[46] Tomás G, Merino S, Martínez-de la Puente J, Moreno J, Morales J, Lobato E. Determinants of abundance and effects of blood-sucking flying insects in the nests of a hole nesting bird. Oecologia 2008; 156: 305-12.

[47] Martínez-de la Puente J, Merino S, Tomás G, et al. Factors affecting Culicoides species composition and abundance in avian nests. Parasitology 2009; 136: 1033-41.

[48] Tomas G, Merino S, Moreno J, Morales J, Martínez-de la Puente J. Impact of blood parasites on immunoglobulin level and parental effort: a medication field experiment on a wild passerine. Funct Ecol 2007; 21:125-33.

[49] Martínez-de la Puente J, Merino S, Lobato E, et al. Does weather affect biting fly abundance in avian nests? J Avian Biol 2009; in press.

[50] Burtt EHJr, Chow W, Babbitt GA. In: Loye JE, Zuk M, Ed. Occurrence and demography of mites of tree swallow, house wren, and eastern bluebird nests, Oxford. UK: Oxford University Press 1991; $104-22$.

[51] Saino N, Incagli M, Martinelli R, Ambrosini R, Møller AP. Immunity, growth and begging behaviour of nestling barn swallows $\mathrm{Hi}$ rundo rustica in relation to hatching order. J Avian Biol 2001; 32: 263-70.

[52] Valera F, Hoi H, Darolova A, Kristofik J. Size versus health as a cue for host choice: a test of the tasty chick hypothesis. Parasitology 2004; 129: 59-68.

[53] Bize P, Jeanneret C, Klopfenstein A, Roulin A. What makes a host profitable? Parasites balance host nutritive resources against immunity. Amer Nat 2008;171: 107-18.

[54] Masello JF, Choconi RG, Helmer M, Kremberg T, Lubjuhn T, Quillfeldt P. Do leucocytes reflect condition in nestling burrowing parrots Cyanoliseus patagonus in the wild? Comp Biochem Phys A. $2009 ; 152: 176-81$

[55] Tschirren B, Bischoff LL, Saladin V, Richner H. Host condition and host immunity affect parasite fitness in a bird-ectoparasite system. Funct Ecol 2007; 21: 372-8.

[56] Václav R, Calero-Torralbo MA, Valera F. Ectoparasite load is linked to ontogeny and cell-mediated immunity in an avian host system with pronounced hatching asynchrony. Biol J Linn Soc 2008; 94: 463-73.

[57] Heeb P, Werner I, Kölliker M, Richner H. Benefits of induced host responses against an ectoparasite. Proc R Soc Lond B 1998; 265: 51-6.

[58] Saino N, Ferrari R, Romano M, Martinelli R, Møller AP. Experimental manipulation of egg carotenoids affects immunity of barn swallow nestlings. Proc R Soc Lond B 2003; 270: 2485-9.

[59] De Neve L, Fargallo JA, Vergara P, Lemus JA, Jarén-Galán M, Luaces I. Effects of maternal carotenoid availability in relation to sex, parasite infection and health status of nestling kestrels (Falco tinnunculus). J Exp Biol 2008; 211: 1414-25.

[60] Lobato E, Merino S, Morales J, et al. Sex differences in circulating antibodies in nestling pied flycatchers. Ibis 2008; 150: 799-806.

[61] Fargallo JA, Laaksonen T, Pöyri V, Korpimäki E. Inter-sexual differences in the immune response of eurasian kestrel nestlings under food shortage. Ecol Lett 2002; 5: 95-101.

[62] Fargallo JA, Martínez-Padilla J, Toledano-Díaz A, SantiagoMoreno J, Dávila JA. Sex and testosterone effects on growth, immunity and melanin coloration of nestling Eurasian Kestrels. J Anim Ecol 2007; 76: 201-09.

[63] Potti J, Merino S. Parasites and the ontogeny of sexual size dimorpishm in a passerine bird. Proc R Soc Lond B 1996; 263: 9-12.

[64] Badyaev AV, Hamstra TL, Oh KP, Acevedo Seaman DA. Sexbiased maternal effects reduce ectoparasite-induced mortality in a passerine bird. Proc Natl Acad Sci USA 2006; 103: 14406-11.

[65] Merino S, Potti J. Weather dependent effects of ectoparasites on their bird host. Ecography 1996; 19: 107-13.
[66] Merino S, Møller AP, de Lope F. Seasonal changes in cellmediated immunocompetence and mass gain in nestlings barn swallows: a parasite-mediated effect? Oikos 2000; 90: 327-32.

[67] Rogers CA, Robertson RJ, Stutchbury BJ. In: Loye JE, Zuk M, Eds. Patterns and effects of parasitism by Protocalliphora sialia on tree swallow nestlings, Oxford. UK: Oxford University Press 1991; 123-39.

[68] Tschirren B, Richner H. Parasites shape the optimal investment in immunity. Proc R Soc Lond B 2006; 273: 1773-7.

[69] Brzek P, Konarzewski M. Relationship between avian growth rate and immune response depends on food availability. J Exp Biol 2007; 210: 2361-7.

[70] Moreno J, Merino S, Sanz JJ, Arriero E, Morales J, Tomás G. Nestling cell-mediated immune response, body mass and hatching date as predictors of local recruitment in the pied flycatcher Ficedula hypoleuca. J Avian Biol 2005; 36: 251-60.

[71] Cichon M, Dubiec A. Cell-mediated immunity predicts the probability of local recruitment in nestling blue tits. J Evol Biol 2005; 18: 962-6.

[72] Lobato E, Moreno J, Merino S, Sanz JJ, Arriero E. Haematological variables are good predictors of recruitment in nestling pied flycatchers (Ficedula hypoleuca). Ecoscience 2005; 12: 27-34

[73] Christe P, de Lope F, González G, Saino N, Møller AP. The influence of environmental conditions on immune responses, morphology and recapture probability of nestling house martins (Delichon urbica). Oecologia 2001; 126: 333-8.

[74] Adamo SA. How should behavioural ecologists interpret measurements of immunity? Anim Behav 2004; 68: 1443-9.

[75] Forsman AM, Vogel LA, Sakaluk SK, Grindstaff JL, Thompson CF. Immune-challenged house wren broods differ in the relative strengths of their responses among different axes of the immune system. J Evol Biol 2008; 21: 873-8.

[76] Møller AP, Arriero E, Lobato E, Merino S. A review of parasite virulence in nestling birds. Biol Rev 2009; 84: 561-88.

[77] Merino S, Moreno J, Vásquez RA, et al. Haematozoa in forest birds from southern chile: latitudinal gradients in prevalence and parasite lineage richness. Austral Ecol 2008; 33: 329-40.

[78] Møller AP, Martín-Vivaldi M, Merino S, Soler JJ. Densitydependent and geographical variation in a immune response in birds. Oikos 2006; 115: 463-74

[79] Arriero E, Moreno J, Merino S, Martínez J. Habitat effects on physiological stress response in nestling blue tits are mediated through parasitism. Phys Biochem Zool 2008; 81:195-203.

[80] Merino S, Martínez J, Barbosa A, et al. Increase in a heat shock protein from blood cells in response to parasitism of nestling house martins (Delichon urbica): an experimental approach. Oecologia 1998; 116: 343-7.

[81] Merino S, Martínez J, Møller AP, Barbosa A, de Lope F, Rodríguez-Caabeiro F. Physiological and haematological consequences of a novel parasite on the red-rumped swallow Hirundo daurica. Int J Parasitol 2001; 31: 1187-93.

[82] Møller AP, Merino S, Brown CR, Robertson RJ. Immune defense and host sociality: a comparative study of swallows and martins. Amer Nat 2001; 158:136-45.

[83] Martin TE, Møller AP, Merino S, Clobert J. Does clutch size evolve in response to parasites and immunocompetence? Proc Natl Acad Sci USA 2001; 98: 2071-6.

[84] Bensch S, Stjernman M, Hasselquist D, et al. Host specificity in avian blood parasites: a study of Plasmodium and Haemoproteus mitochondrial DNA amplified from birds. Proc R Soc Lond B 2000; 267:1583-9.

[85] Graczyk T, Brossy JJ, Sanders ML, Dubey JP, Plös A, Stoskopf MK. Immunological survey of babesiosis (Babesia peircei) and toxoplasmosis in jackass penguins in South Africa. Parasite1996; 4 : 313-9.

[86] Dolnik OV, Palinauskas V, Bensch S. Individual oocysts of Isospora (Apicomplexa: Coccidia) parasites from avian feces: from photo to sequence. J Parasitol 2009; 95: 169-74.

[87] Höfle U, Blanco JM, Crespo E, et al. West Nile virus in the endangered Spanish imperial eagle. Vet Microbiol 2008; 129: 171-8.

[88] Martin II LB, Han P, Lewittes J, Kuhlman JR, Klasing KC, Wikelski M. Phytohemagglutinin-induced skin swelling in birds: histological support for a classic immunoecological technique. Funct Ecol 2006; 20: 290-9.

[89] Matson KD, Ricklefs RE, Klasing KC. A hemolysishemagglutination assay for characterizing constitutive innate hu- 
moral immunity in wild and domestic birds. Develop Comp Immunol 2005; 29: 275-86.

[90] Matson KD, Cohen AA, Klasing KC, Ricklefs RE, Scheuerlein A. No simple answers for ecological immunology: relationships among immune indices at the individual level break down at the species level in waterfowl. Proc R Soc Lond B 2006; 273: 815-22.

[91] Lobato E, Merino S, Moreno J, et al. Corticosterone metabolites in blue tit and pied flycatcher droppings: effects of brood size, ectoparasites and temperature. Horm Behav 2008; 53: 295-305.

[92] Merino S, Martínez J, Møller AP, et al. Phytohemagglutinin injection assay and physiological stress in nestling house martins. Anim Behav 1999; 58: 219-22.
[93] Fessl B, Kleindorfer S, Tebbich S. An experimental study on the effects of an introduced parasite in darwin's finches. Biol Cons 2006; 127: 55-61.

[94] Huber SK. Effects of the introduced parasite Philornis downsi on nestling growth and mortality in the medium ground finch (Geospiza fortis). Biol Cons 2008; 141: 601-9.

[95] Reed KD, Meece JK, Henkel JS, Shukla SK. Birds, migration and emerging zoonoses: West nile virus, lyme disease, influenza A and enteropathogens. Clin Med Res 2003; 1: 5-12.

(c) Santiago Merino; Licensee Bentham Open.

This is an open access article licensed under the terms of the Creative Commons Attribution Non-Commercial License (http://creativecommons.org/licenses/_by-nc/3.0/) which permits unrestricted, non-commercial use, distribution and reproduction in any medium, provided the work is properly cited. 